\title{
高張力鋼箱形断面部材の局部座屈と変形能力 DEFORMATION CAPACITY OF WELDED SQUARE HOLLOW SECTION MEMBERS MADE OF HIGH STRENGTH STEEL GOVERNED BY LOCAL BUCKLING
}

\author{
加藤 勉 ${ }^{*}$, 井上哲 郎** \\ Ben KATO and Tetsuro INOUE
}

\begin{abstract}
The plastic deformation capacity of welded steel hollow section members subjected to bending and combined bending and axial compression is analysed theoretically, and the test results are compared with this theoretical prediction. Steel material used is the newly developed highstrength steel with lower yield ratio. Dimensions of sections are so selected that the maximum strength and deformation capacity are governed by the local buckling of plate elements. In the theoretical prediction, the deformation capacity is related to the width-to-thickness ratios of section elements. Therefore the width-to-thickness ratio limitation can be obtained if the required rotation capacity of member is assigned.
\end{abstract}

Keywords : high-strength steel, local buckling, ductility, box section 高張力鋼; 局部座屈, 変形能力, 箱形断面

\section{1. 序}

本研究は比較的降伏比の低い 60 キ口級高張力鋼の箱 形断面部材が定軸力（軸力零も含む）下で曲げをうけ， 板要素の局部座屈で耐力および変形能力が決まる場合に ついて,その塑性変形能力を短柱圧縮試験から得た知見 を用いて理論的に求め, 部材実験によってこれを検証し たものである。軸力と曲げをうける部材の非弾性解析は 高次の非線形問題で通常数值解析が用いられるが, 本研 究では部材をモデル化して数学的手法によって閉じた形 の一般的な解を求め, 主要なパラメータの奇与の度合い が見えるようにしている。解析の手法を要約すると，正 方形中空断面を等価なパラレルフランジ断面に置き換 え，このモデル化した部材の荷重一変形関係を圧縮側フ ランジ内の応力を媒介変数として求める。一方, 正方形 中空断面の幅厚比を変数とする一連の短柱圧縮試験（ タブカラムテスト）を行い，局部座屈で決まる最大応力 度と幅厚比の関係式を統計的手法で求める。この局部座 屈最大応力度を, 先の荷重-変形関係式の圧縮フランジ 応力度に等置することにより, 局部座屈崩壊時の柱の変 形を求めるものである。この手法は既に他の論文”で用 いたが，これを多少修正したこと，および論旨を明確に するために，最初に再度その要約を揭げる。

\section{2. 定軸力下で曲げをうける部材の解析}

鋼材の応力ーひずみ関係を剛塑性モデルで表す。部材 の変形能力を塑性変形成分のみの項で表す場合このモデ ルは便利である。また全領域にわたる応力ーひずみ関係 をFig. 1 に示すごとく 4 線分で表す。

変形解析においては, 部材のせん断変形および軸力に よる部材の付加曲げ効果を無視する。箱形断面ではウェ ブの断面積が相対的に大きいのでせん断変形量は小さ く，通常の多層建物の柱の細長比の範囲では軸力による 付加曲げ効果は極めて小さい。

正方形中空断面を等価なパラレルフランジ断面に置換 して用いる (Fig. 2 参照)。置換は両断面において全塑

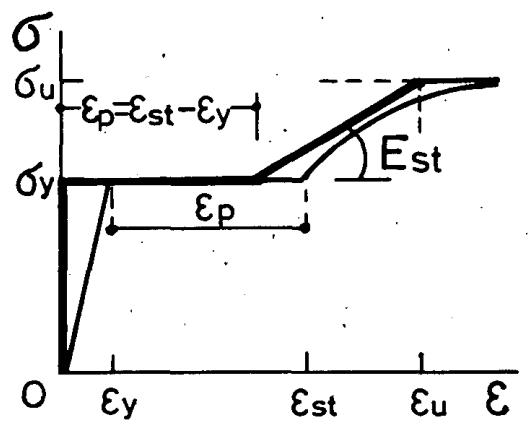

Fig. 1 Rigid-plastic model
* 東洋大学工学部 教授. 工博

** 筑波大学構造工学系 助教授・工博
Prof., Toyo Univ., Faculty of Engineering, Dr. Eng.

Assoc. Prof., Tsukuba Univ., Faculty of Engineering, Dr. Eng. 


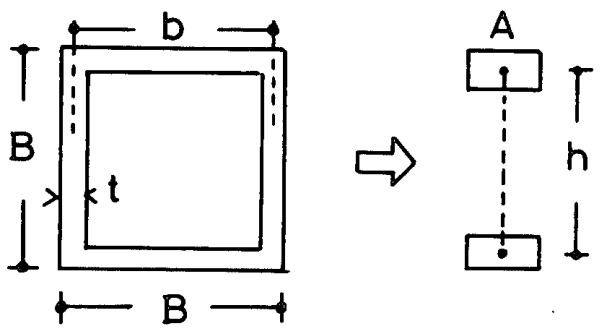

Fig. 2 Parallel flange model

性モーメント $\left(M_{p}\right)$ および断面積が等しくなるように 行った。置換断面の断面二次モーメント $(I)$ と断面せい $(h)$ と実断面の断面二次モーメント $\left(I_{a}\right)$, 断面幅 $(b)$ との 関係はそれぞれ次のようになる。

$$
I=\frac{27}{32} I_{a}, \quad h=\frac{3}{4} b
$$

2.1 モーメント曲率関係 $(M-\phi$ 関係)

Case 1. $\rho>\frac{s-1}{2}$ のとき

この場合は崩壊に至るまで引張側フランジは降伏しな い。ここに $\rho=P / P_{y}$ : 軸力比, $P$ : 作用軸力, $P_{y}=2$ $A \sigma_{y}$ : 降伏軸力, $A$ : 置換断面の 1 つのフランジの断面 積 (実断面積の $1 / 2$ ), $s=\sigma_{u} / \sigma_{y}$ : 応力上昇率, $\sigma_{u}$ : 圧 縮フランジが耐えうる最大応力度, $\sigma_{y}$ : 材料の降伏点

1） $\phi \leq \phi_{p}$ の区間（圧縮フランジのひずみが塑性流れ域 にある)

$$
M=(1-\rho) M_{p}
$$

記号 $: \phi_{\rho}=\varepsilon_{\rho} / h:$ 圧縮 フランジのひずみが昰硬化点 に達した時の曲率

$\varepsilon_{p}=\varepsilon_{s t}-\varepsilon_{y}:$ 删塑性モデルにおける塑性流れひ ずみ (Fig. 1 参照)

$\phi=\varepsilon / h:$ 圧縮フランジひずみが $\varepsilon$ の時の曲率 $\varepsilon_{s t}:$ 材料のひずみ硬化開始点のひずみ $\varepsilon_{y}=\sigma_{y} / E:$ 降伏ひずみ

$M_{p}=A h \sigma_{y} ：$ 全塑性モーメント

2） $\phi_{p}<\phi \leq \phi_{u}$ の区間（圧縮フランジのひずみがひずみ 硬化域にある)

$$
M=(1-\rho) M_{\rho}+D\left(\phi-\phi_{\rho}\right)
$$

記号 : $D=2 E_{s t} I:$ ひず硬化域における断面の曲げ 用性

$E_{s t}:$ 材料のひずみ硬化係数 (Fig. 1 参照)

$$
I=\frac{1}{2} A h^{2}: \text { 断面二次モーメント }
$$

曲げモーメントの上限 $M_{u}$ は

$$
M_{u}=(s-\rho) M_{p}
$$

この時の限界曲率 $\phi_{u}$ は，（3）式の $M_{u}$ を（2）式に入 れて,

$$
\phi_{u}=\left(\frac{s-1}{D}\right) M_{\rho}+\phi_{\rho}
$$

Case 2. $0<\rho \leq \frac{s-1}{2}$ のとき
この場合は圧縮フランジ降伏後, 崩壊に至る途中で引 張フランジも降伏する。ただし引張フランジの応力度は 最大応力度には達しない。

引張フランジが降伏するまでは $\boldsymbol{M - \phi}$ 関係は Case 1 の場合と全く同じである。引張フランジが降伏する時の モーメントは

$$
M=A h\left(\sigma_{0}+\sigma_{y}\right)=(1+\rho) M_{p}
$$

ここに $\sigma_{0}=\frac{P}{2 A}$ : 軸王縮力 $P$ によってフランジに生ず る応力度である。

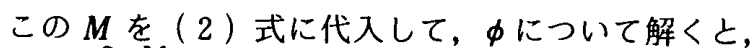
$\phi=\phi_{p}+\frac{2 \rho M_{p}}{D}$ となる。すなわち (2) 式の適用範囲お よび曲げモーメントは,

2) $\phi_{p}<\phi \leq \phi_{p}+\frac{2 \rho M_{p}}{D}$ の区間

$$
M=(1-\rho) M_{p}+D\left(\phi-\phi_{p}\right)
$$

となる。

引張フランジが降伏すると直ちに塑性流れを起こす。 この塑性流れによる曲率の増加は $\phi_{p}$ である。この間曲 げモーメントは一定値 $M=(1+\rho) M_{p}$ を保つ。したがっ てこの区間に対する記述は

3) $\phi_{\rho}+\frac{2 \rho M_{\rho}}{D}<\phi \leq 2\left(\phi_{\rho}+\frac{\rho M_{\rho}}{D}\right)$ の区間

$$
M=(1+\rho) M_{\rho}
$$

となる。

さらに曲げモーメントが増大すると, 引張フランジ内 のひずみもひずみ硬化域に入る。この領域における断面 の曲げ剛性 $D^{\prime}$ は

$$
D^{\prime}=\frac{\Delta M}{\Delta \phi}=\frac{h A \Delta \sigma}{(2 \Delta \varepsilon / h)}=\frac{1}{2} A h^{2}\left(\frac{\Delta \sigma}{\Delta \varepsilon}\right)=E_{s t} I=D / 2
$$

となる。

したがってこの区間における $M-\phi$ 関係は次のように なる。

4) $2\left(\phi_{p}+\frac{\rho M_{p}}{D}\right)<\phi \leq \phi_{u}$ の区間

$$
\begin{aligned}
& M=(1+\rho) M_{p}+\frac{D}{2}\left[\phi-2\left(\phi_{\rho}+\frac{\rho M_{p}}{D}\right)\right] \\
& =M_{p}+D\left(\frac{\phi}{2}-\phi_{p}\right)
\end{aligned}
$$

(6) 式は, この区間の開始点は $\rho$ の関数であるが, $M-\phi$ 関係は $\rho$ に無関係であることを示している。

曲げモーメントの上限は (3) 式と同じであり, 対応 する限界曲率 $\phi_{u}$ はこの上限モーメントを（6）式に代 入して,

$$
\phi_{u}=2\left[\phi_{p}+\frac{(s-\rho-1) M_{\rho}}{D}\right]
$$

である。

Case 3. $\rho=0$ のとき（はりの場合）

この場合は圧縮フランジと引張フランジが同時に降伏 し，同時に塑性流机域に入る。 


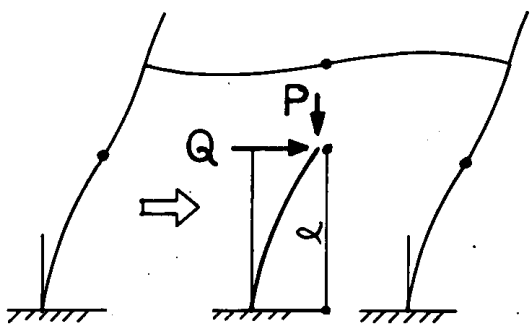

Fig. 3 Cantilever beam-column model

1) $\phi \leq 2 \phi_{\rho}$ の区間では両フランジのひずみは塑性流れ 域に留まり，その曲げモーメントは

$$
M=M_{p}
$$

2) $2 \phi_{p}<\phi \leq \phi_{u}$ の区間では両フランジのひずみがひず み硬化域に入るが，この状態は Case 2 の）と同じで あり，したがって $M-\phi$ 関係は（6）式によって与えら れる。

$$
M=M_{p}+D\left(\frac{\phi}{2}-\phi_{p}\right)
$$

曲げモーメントの上限は

$$
M_{u}=s M_{\rho}
$$

対応する限界曲率 $\phi_{u}$ は $(9)$ 式の $M_{u}$ を（6）式に入 れて,

$$
\phi_{u}=2\left[\phi_{p}+\frac{(s-1) M_{p}}{D}\right]
$$

2.2 軸力と曲げをうける柱の塑性変形能力（ヒンジ回 転能力)

本論文では主として水平力をうける多層ラーメンの柱 の塑性変形能力を問題とするので，これをFig. 3 に示 すような一端固定他端自由の柱の頂部に軸圧縮力之水平 力が作用する問題に置き換えて論ずる。この問題の精密 解を求めることもできるが゙)，解の表現が複雑になり実 用的でないので，冒頭に述べたごとく，軸力による部材 の付加曲げ効果を無視する。多層建築の柱の細長比は小 さいので付加曲げの効果を無視しても実質的な誤差は生 じない。

Case 1. $\quad \rho>\frac{s-1}{2}$ のとき

Fig. 4 はFig. 3 に示した定軸力と曲げをうける片持 柱の終局状態における曲げモーメント図と，変形模式図 である。図で降伏は A点で始まっており, B点で終局モ一 メントに達している。図から塑性化域の長さ $\lambda l$ は幾何 学的に（11）式のように算出される。

$$
\lambda l=\left(\frac{s-1}{s-\rho}\right) l .
$$

座標 $x, y$ を材長 $l$ で無次元化してそれぞれ $X=x / l$, $Y=y / l$ とする。

$X$ 点 $(0 \leq X \leq \lambda)$ における曲げモーメントは

$$
M=(s-\rho) M_{p}-(s-\rho) M_{p} X
$$

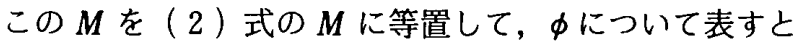

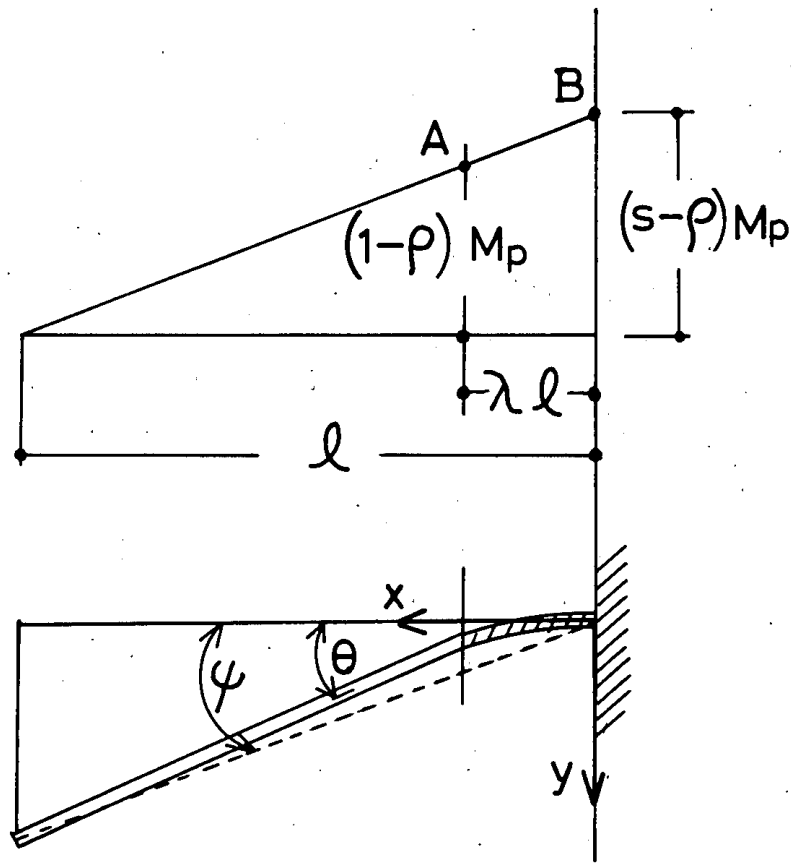

Fig. 4 Configuration of beam-column $\rho>(s-1) / 2$

$$
\begin{aligned}
\phi=\frac{d^{2} y}{d x^{2}} & =\frac{M_{\rho}}{D}(s-1)+\phi_{\rho}-\frac{M_{\rho}}{D}(s-\rho) X \\
\frac{d^{2} Y}{d X^{2}} & =\frac{M_{\rho} l}{D}(s-1)+l \phi_{\rho}-\frac{M_{\rho} l}{D}(s-\rho) X
\end{aligned}
$$

（13）式を積分して，撓み曲線の接線勾配 $\theta_{X}$ を得る。

$$
\theta_{X}=\frac{d Y}{d X}=\left[\frac{M_{\rho} l}{D}(s-1)+l \phi_{\rho}\right] X-\frac{M_{\rho} l}{2 D}(s-\rho) X^{2}
$$

終局状態における部材先端の勾配 (slope) $\theta_{c r}$ は, (14) 式に $X=\lambda=\frac{s-1}{s-\rho}$ を入れて，

$$
\theta_{c r}=\frac{M_{\rho} l}{2 D} \cdot \frac{(s-1)^{2}}{s-\rho}+l \phi_{\rho}\left(\frac{s-1}{s-\rho}\right)
$$

さらに(14) 式を積分すると

$$
Y=\frac{1}{2}\left[\frac{M_{p} l}{D}(s-1)+l \phi_{p}\right] X^{2}-\frac{M_{p} l}{6 D}(s-\rho) X^{3}
$$

塑性化域先端 $A$ におけるたわみ $Y_{A}$ は,

$$
Y_{A}=\frac{M_{\rho} l}{3 D} \cdot \frac{(s-1)^{3}}{(s-\rho)^{2}}+\frac{l \phi_{\rho}}{2} \cdot \frac{(s-1)^{2}}{(s-\rho)^{2}}
$$

部材先端のたわみは. $Y_{c r}=Y_{A}+(1-\lambda) \theta_{c r}$ であり, $(15)$, (17) 式を用いて,

$$
\begin{aligned}
Y_{c r}= & \frac{(s-1) l}{2(s-\rho)^{2}}\left[\frac{M_{p}}{3 D}(s-1)(1+2 s-3 \rho)\right. \\
& \left.+(s+1-2 \rho) \phi_{p}\right] \ldots \ldots \ldots \ldots \ldots \ldots \ldots \ldots \ldots \ldots \ldots \ldots \ldots \ldots
\end{aligned}
$$

となる。

無次元たわみは $Y=y / l$ であり，部材角 $\psi$ に当たる。 部材の変形能力（回転能力）は, 接線角 $\theta$ 又は部材 角 $\psi$ によって下記のごとく表現される。 


$$
\begin{aligned}
& \eta_{\theta}=\frac{\theta_{u}}{\theta_{y}}-1=\frac{\theta_{u}-\theta_{y}}{\theta_{y}}=\frac{\theta_{c r}}{\theta_{y}} \ldots \\
& \eta_{\psi}=\frac{\phi_{u}}{\psi_{y}}-1=\frac{\phi_{u}-\phi_{y}}{\psi_{y}}=\frac{\psi_{c r}}{\psi_{y}}
\end{aligned}
$$

上式の $\theta_{u} ， \psi_{u}$ はいずれも弾性成分，塑性成分を含め た材全体の変形であり, 変形能力の定義は塑性変形成分 の降伏変形量に対する比率ということになる。

本論文で求めた $\theta_{c r}[(15)$ 式 $]$ および $Y_{c r}=\psi_{c r}[(18)$ 式は塑性変形成分のみによる角度であるから，これら を降伏時の変形角で除すれば変形能力となる。

固定端降伏時の材先端接線角 $\theta_{y}$ および部材角 $\phi_{y}$ はそ れぞれ次のように表される。

$$
\begin{aligned}
& \theta_{y}=\frac{(1-\rho) M_{\rho} l}{2 E I} \ldots \ldots . . \\
& \phi_{y}=Y_{y}=\frac{(1-\rho) M_{\rho} l}{3 E I} .
\end{aligned}
$$

したがって $\eta_{\theta}, \eta_{\psi}$ はそれぞれ（15）式と（21）式お よび（18）式と（22）式を用いて次のように表される。

$$
\begin{aligned}
\eta_{\theta}= & \frac{(s-1)}{2(1-\rho)(s-\rho)}\left[\frac{E}{E_{s t}}(s-1)+2\left(\frac{\varepsilon_{\rho}}{\varepsilon_{y}}\right)\right] \cdots(23) \\
\eta_{\psi}= & \frac{(s-1)}{4(s-\rho)^{2}(1-\rho)}\left[\frac{E}{E_{s t}}(s-1)(1+2 s-3 \rho)\right. \\
& \left.+3\left(\frac{\varepsilon_{\rho}}{\varepsilon_{y}}\right)(1+s-2 \rho)\right] \cdots \cdots \cdots \cdots \cdots \cdots \cdots(24)
\end{aligned}
$$

Case 2. $0<\rho \leq \frac{s-1}{2}$ のとき

本論文では部材板要素の局部座屈によって変形能力が 支配される問題を研究対象としている。局部座屈で最大 圧縮応力度が決まる場合は後述のごとく応力上昇率 $s$ は高々 1.3 程度である。したがって Case 2 に属する柱 の軸力比は 0.15 以下となり実用的興味に乏しい。Case 2 の場合も Case 1 と同様の計算によって変形能力を求
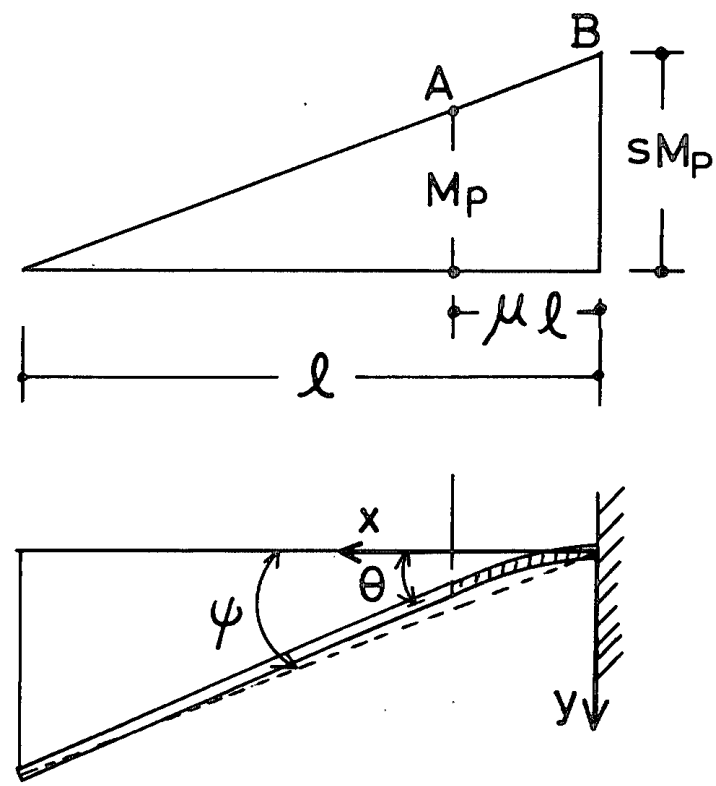

Fig. 5 Configuration of beam $\rho=0$
めることができる2が，材長に沿って 2 種類の塑性域が 存在することになるので解は複雑となる。よってこの荷 重条件に対する記述は省略する。

Case 3. $\rho=0$ のとき (はりの場合)

この場合は圧縮, 引張両フランジが同時に降伏して, 塑性化が進行する。終局状態におけるはりのモーメント 分布および変形は Fig. 5 のようになり, 無次元塑性化 領域長さ $\mu$ は単純な幾何学より

$$
\mu=\frac{s-1}{s}
$$

$X$ 点 $(0 \leq X \leq \mu)$ における曲げモーメントは

$$
M=s M_{p}(1-X) \text {. }
$$

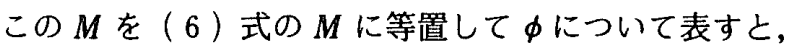

$$
\begin{aligned}
\phi=\frac{d^{2} y}{d x^{2}} & =\frac{2(s-1)}{D} M_{\rho}+2 \phi_{\rho}-\frac{2 s}{D} M_{p} X \\
\frac{d^{2} Y}{d X^{2}} & =\frac{2(s-1)}{D} M_{\rho} l+2 l \phi_{\rho}-\frac{2 s}{D} M_{\rho} l X
\end{aligned}
$$

(27）式を積分してたわみ曲線の接線勾配 $\theta_{x}$ を得る。

$$
\theta_{X}=\frac{d Y}{d X}=\left[\frac{2(s-1)}{D} M_{p} l+2 l \phi_{p}\right] X-\frac{s}{D} M_{p} l X^{2}
$$

終局状態における部材先端の勾配 $\theta_{c r}$ は（28）式に $X$ $=\mu=\frac{s-1}{s}$ を入れて,

$$
\theta_{c r}=\frac{s-1}{s}\left[\frac{(s-1) M_{\rho} l}{D}+2 l \phi_{\rho}\right]
$$

さらに（28）式を積分すると,

$$
Y=\frac{1}{2}\left[\frac{2(s-1)}{D} M_{\rho} l+2 l \phi_{\rho}\right] X^{2}-\frac{s}{3 D} M_{\rho} l X^{3}
$$

塑性化域先端 $A$ におけるたわみ $Y_{A}$ は,

$$
Y_{A}=\frac{2}{3} \cdot \frac{(s-1)^{3}}{D s^{2}} M_{\rho} l+l \phi_{p} \frac{(s-1)^{2}}{s^{2}}
$$

部材先端のたわみは, $Y_{c r}=Y_{A}+(1-\mu) \theta_{c r}$ であり, $(29)$, (31) 式を用いて

$$
\psi_{c r}=Y_{c r}=\frac{s-1}{s^{2}}\left[\frac{M_{\rho} l}{3 D}(s-1)(2 s+1)+l \phi_{p}(s+1)\right]
$$

固定端降伏時の材先端接線角 $\theta_{y}$ および部材角 $\psi_{y}$ はそ れぞれ次のように表される。

$$
\begin{aligned}
& \theta_{y}=\frac{M_{p} l}{2 E I} \ldots \ldots . . . \\
& \phi_{y}=Y_{y}=\frac{M_{p} l}{3 E I}
\end{aligned}
$$

したがって $\eta_{\theta} ， \eta_{\Psi}$ はそれぞれ (29)，(33）式，および (32)，(34）式を用いて,

$$
\eta_{\theta}=\frac{s-1}{s}\left[\frac{E}{E_{s t}}(s-1)+2 \frac{\varepsilon_{p}}{\varepsilon_{y}}\right]
$$




$$
\eta_{\psi}=\frac{s-1}{2 s^{2}}\left[\frac{E}{E_{s t}}(s-1)(1+2 s)+3\left(\frac{\varepsilon_{p}}{\varepsilon_{y}}\right)(1+s)\right]
$$

\section{3. 局部座屈を伴う正方形中空断面短拄の最大圧縮耐力}

60 キ口級高張力鎆を溶接集成して作った正方形中空 断面短柱の圧縮実験の結果については既に報告した³)。 本研究の目的は非弾性局部座屈強さと幅厚比との関係を 求めることにあるので，同実験のうち，弾性域で局部座 屈を起こしたものは除外した。また長さの短かい柱（同 論文の A シリーズ）では材端拘束度が座屈波の発生を乱 すので, $\mathrm{A}$ シリーズの実験結果を除外し，結局 11 体の 試験結果を用いて，局部座屈最大応力度〜幅厚比関係を 求めた。

一般に板の非弾性局部座屈強さは次式で表される。

$$
\sigma_{\mathrm{cr}}=K E_{r}\left(\frac{t}{B}\right)^{2}
$$

ここに $E_{r}=$ 塑性域における鋼の低減弾性係数, $K=$ 支持条件，ポアソン比によって決まる係数

（37）式の両辺を降伏点 $\sigma_{y}$ で除して応力上昇率 $s$ の 形で表すと次式のようになる。

$$
s_{c r}=\frac{\sigma_{c r}}{\sigma_{y}}=f\left(\sigma_{y}, \nu, E_{r} / E\right) \cdot \frac{E}{\sigma_{y}}\left(\frac{t}{B}\right)^{2},
$$$$
\text { または } s_{c r}=f \cdot a
$$

$\alpha=\frac{E}{\sigma_{y}}\left(\frac{t}{B}\right)^{2}$ は無次元座屈パラメータであり， $f$ は残留 応力, 塑性域におけるポアンン比, 低減弾性係数によっ て決まる係数である。この $f$ の值を上記の実験結果を 用いて決める。実験より得た $s_{c r}$ の值と $\alpha$ を用いて， $1 / s \sim 1 / \alpha$ 関係を図上にプロットすると Fig. 6 のように なる。

\section{これを直線回帰すると次式が得られる。}

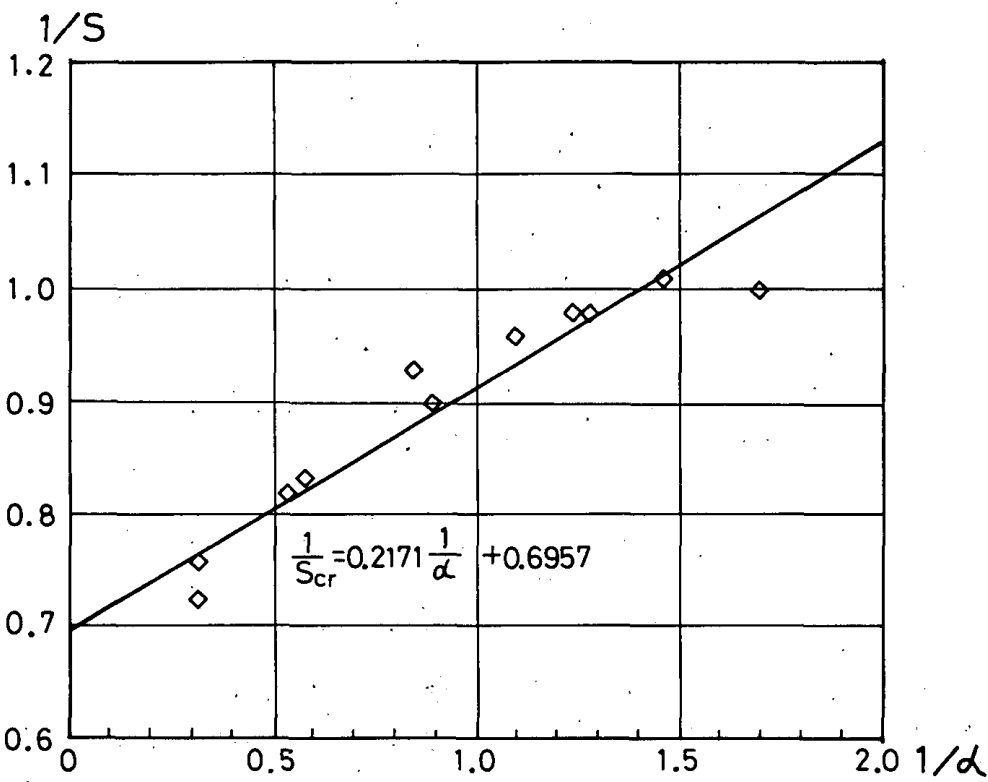

Fig. $61 / s \sim 1 / \alpha$ Relationship

$$
\frac{1}{s_{c r}}=0.2171 \frac{1}{\alpha}+0.6957 \text {. }
$$

標準偏差 $\sigma=0.01077$

（39）式は無次元座屈パラメータ（幅厚比） $\alpha$ と局部 座屈で決まる応力上昇率との関係を与える。

\section{4. 変形能力の予測と実験結果との比較}

\section{1 変形能力の予測}

部材フランジの応力度 (応力上昇率) が 3 . で得た $s_{c r}$ に達すると, 局部座屈によって部材耐力および変形 能力は限界に達すると考えられるから，(39) 式の $s_{c r}$ を2. で得た変形能力予測式 (23), (24) 式 $\left(\rho>\frac{s-1}{2}\right)$, $(35),(36)$ 式 $(\rho=0)$ の $s$ 等置することにより, 部 材の変形能力 $\eta$ と断面の幅厚比 $(B / t)$, 鋼の機械的諸常 数との関係を得ることができる。

（39）式は中心圧縮実験から得られたものであり，断 面を構成する 4 枚の鋼板は等しい均等圧縮応力をうけて 來屈している。これに対して，曲げと圧縮（または曲げ） をうける部材ではウェブに当る鋼板には応力勾配を生 じ，座屈に対して有利となるので，この点を考慮する必 要がある。応力勾配のある鋼板の座屈終局耐力に関する 知見はいまだ得られていないのでやや恐意的ではある が，全塑性状態における塑性中立軸に関して王縮側にな る部分をウェブの圧縮幅と考え，下記のような有効幅厚 比を用いることとする。Fig. 7 において，板厚中心線に ついて考えると，軸力比 $\rho$ のとでの塑性中立軸の位 置は $b e=b\left(\frac{1}{2}+\rho\right)$ となる。これをウェブの圧縮幅と考 え, ウェブの圧縮幅とフランジの圧縮幅の平均をもって 等価圧縮幅 $B_{e}$ とし等価幅厚比を次の上うに算出する。

$$
\left.\begin{array}{rl}
0 \leq \rho \leq 0.5: \frac{B_{e}}{t} & =\frac{2 b(0.5+\rho)}{3 t} \\
& =\frac{2}{3} \frac{b}{t}(1+\rho) \\
& =\frac{2}{3}\left(\frac{B}{t}-1\right)(1+\rho) \\
1 \geq \rho>0.5: B_{e} & =B
\end{array}\right\}
$$

次に，(23)，(24）式书よび（35)，(36）式 中のひずみ硬化係数 $E_{s t}$ および $\varepsilon_{p} / \varepsilon_{y}$ の評価 であるが，2.2 の解析は座屈を伴わない部材

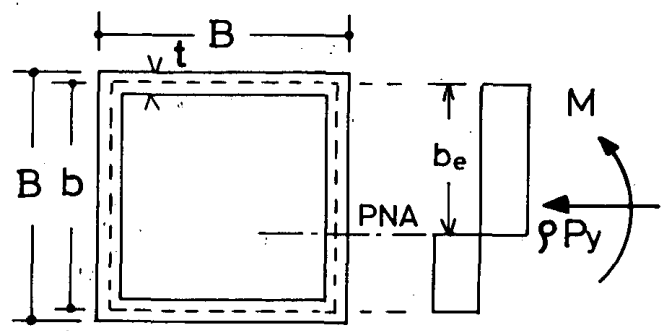

Fig. 7 Plastic neutral axis 


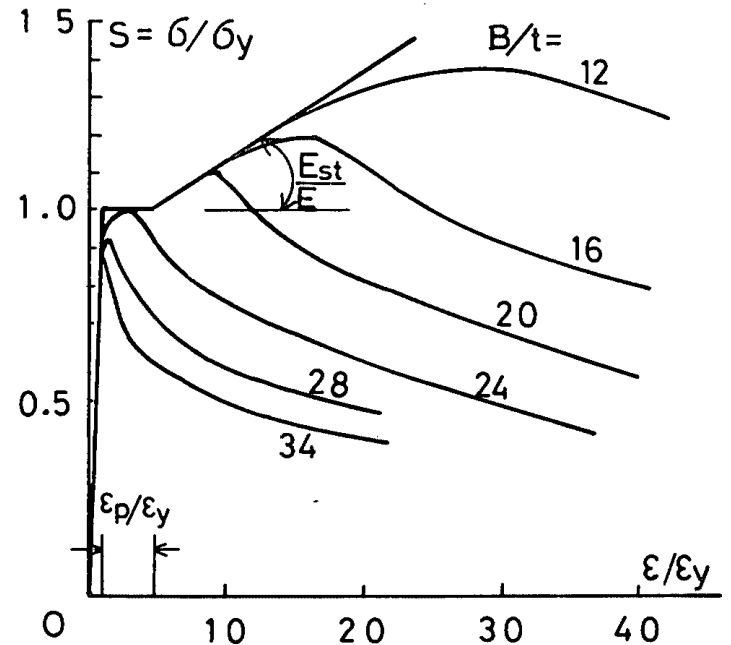

Fig. $8 \sigma / \sigma_{y}-\varepsilon / \varepsilon_{y}$ Relation from stub-column tests

の塑性変形解析であるから, 溶接部の機械的性質変化, 残留応力の影響を含めた短柱圧縮試験の結果から得られ る平均的応力ーひずみ曲線から求めるのが妥当であろう。 Fig. 8 は前記 $)^{31}$ 短柱圧縮試験の結果である。ひずみ硬化 勾配は直線ではないが, 実用範囲の箱形断面では応力上 昇率 $s$ は高々 1.3 程度であるので，この範囲で図示の ように応力ーひずみ関係を三直線線分で近似し $E / E_{s t}$ お よび $\varepsilon_{p} / \varepsilon_{y}$ を求めるとそれぞれ $E / E_{s t}=49.97, \varepsilon_{\rho} / \varepsilon_{y}=$ 4.02 となる。これに対し素材の引張試験から得られた 値はそれぞれ， $E / E_{s t}=48.06 ， \varepsilon_{p} / \varepsilon_{y}=5.24$ であった。

次節で述べるように，部材の実験では部材角 $\phi$ で変 形能力を測定しているので, 理論予測も $\eta_{\psi}$ によって行 う。予测式を要約すると,

(1)

$$
\begin{aligned}
\rho> & \frac{s_{c r}-1}{2} \text { のとき : } \\
\eta_{\psi}= & \frac{\left(s_{c r}-1\right)}{4\left(s_{c r}-\rho\right)^{2}(1-\rho)}\left[\frac{E}{E_{s t}}\left(s_{c r}-1\right)\left(1+2 s_{c r}-3 \rho\right)\right. \\
& \left.+3 \frac{\varepsilon_{\rho}}{\varepsilon_{y}}\left(1+s_{c r}-2 \rho\right)\right] \cdots \cdots \cdots \cdots \cdots \cdots(24)^{\prime}
\end{aligned}
$$

(2) $\rho=0$ のとき

$$
\begin{aligned}
\eta_{\psi}= & \left(\frac { s _ { c r } - 1 } { 2 s _ { c r } ^ { 2 } } \left[\frac{E}{E_{s t}}\left(s_{c r}-1\right)\left(1+2 s_{c r}\right)\right.\right. \\
& \left.+3 \frac{\varepsilon_{\rho}}{\varepsilon_{y}}\left(1+s_{c r}\right)\right] \ldots \ldots \ldots \ldots \ldots \ldots \ldots \ldots \ldots \ldots \ldots \ldots
\end{aligned}
$$

$(24)^{\prime},(36)^{\prime}$ 式において

$$
\begin{aligned}
& \frac{1}{s_{c r}}=0.2171 \frac{\sigma_{y}}{E}\left(\frac{B_{e}}{t}\right)^{2}+0.6957 . \\
& \frac{B_{e}}{t}=\frac{2}{3}\left(\frac{B}{t}-1\right)(1+\rho) \ldots \ldots \ldots \ldots . .
\end{aligned}
$$

$E / E_{s t}=49.97, \varepsilon_{p} / \varepsilon_{y}=4.02$ である。

\section{2 実 験 ${ }^{4}$}

Fig. 9 に示すごとく，定軸力下の単純支持ばりに中央 集中荷重を加える形で実験を行った。部材断面は溶接集 成正方形中空断面で板厚 $6 \mathrm{~mm}$ である。その機械的性質

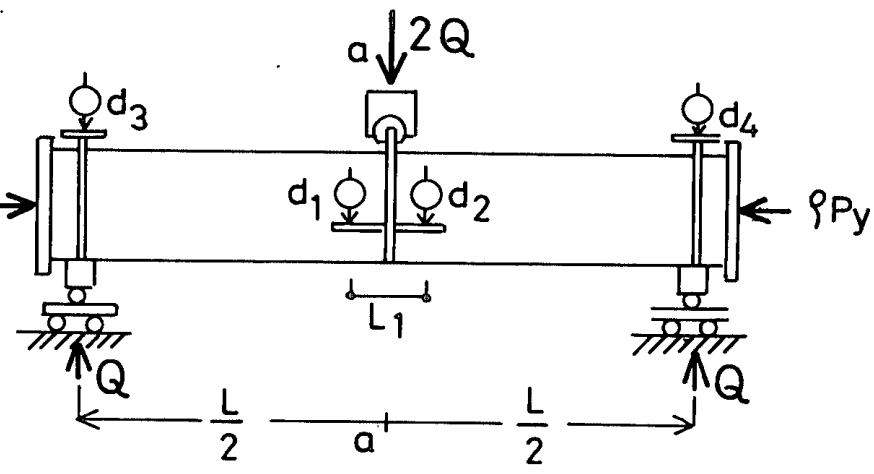

Fig. 9 Loading and deformation measurement ( $d_{t}$ : position of dial gage)

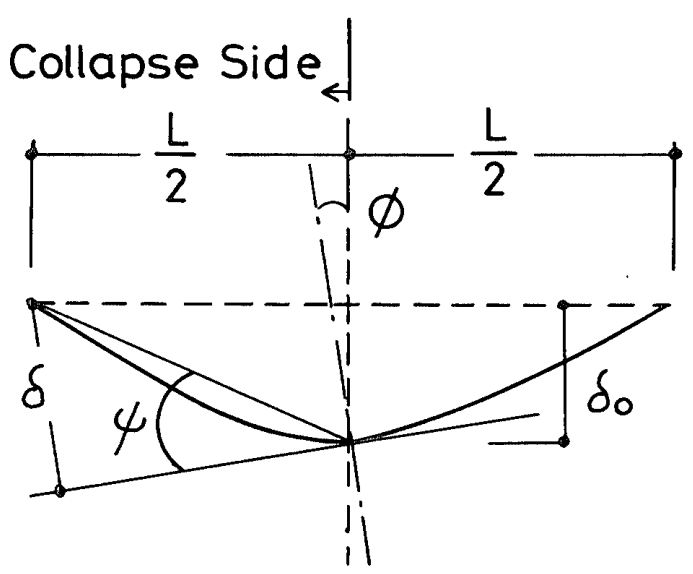

Fig.10 Deflexion mode

は $\sigma_{y}=4.41 \mathrm{t} / \mathrm{cm}^{2}, \sigma_{u}=5.99 \mathrm{t} / \mathrm{cm}^{2}, \varepsilon_{s t}=1.36 \%$ （2 個 の平均）であり短柱実験で用いた鋼と略同等とみなせる ので，座屈特性は（39）式によることとする。

変形測定は終局時において局部座屈崩壊する側の挙動 に着目し，図の中心軸 $a \sim a$ を固定端とする片持ばり形 beam-column の変形として解析モデルを対応させた。 すなわち図の $d_{t}$ をダイアルゲージの読みとすると， Fig. 10 を参照して,

$$
\begin{aligned}
& \phi=\frac{2 \delta}{L}, \quad \delta=\delta_{0}+\frac{\phi L}{2}, \quad \delta_{0}=\left(d_{1}+d_{2}-d_{3}-d_{4}\right) / 2 \\
& \phi=\frac{d_{1}-d_{2}}{L_{1}}-\frac{d_{3}-d_{4}}{L}
\end{aligned}
$$

である。

またスパン中央 (片持梁固定端) の作用曲げモーメン トは

$$
M=\rho P_{y} \delta_{0}+\frac{Q L}{2}
$$

である。

実験変数は設計幅厚比 $B / t=20,24,28,32,34$, 軸 力比 $\rho=0,0.25,0.5$ および部材の細長比 $\lambda=L / i=30$, 40, 50 ( $L=$ 部材長, $i=$ 断面二次半径) とし, これら の組合せで合計 33 体の部材実験を行った。Table 1 に その一覧を示す。表中の幅厚比は実測幅厚比である。表 中の Code 表示は最初のアルファベット $\mathrm{S}$ は $\lambda=30$ の短 
Table 1 List of specimens

\begin{tabular}{|l|c|c|c||c|c|c|c|}
\hline Code & $B / t$ & $\lambda$ & $\rho$ & Code & $B \cdot /$ & $\lambda$ & $\rho$ \\
\hline $\mathrm{S} 20 \cdot 0$ & 19.41 & 30 & 0.00 & $\mathrm{~S} 28 \cdot 0$ & 27.42 & 30 & 0.00 \\
$\mathrm{~S} 20 \cdot 25$ & 19.41 & 30 & 0.25 & $\mathrm{~S} 28 \cdot 25$ & 27.42 & 30 & 0.25 \\
$\mathrm{~S} 20 \cdot 50$ & 19.41 & 30 & 0.50 & $\mathrm{~S} 28 \cdot 50$ & 27.42 & 30 & 0.50 \\
$\mathrm{M} 20 \cdot 0$ & 19.46 & 40 & 0.00 & $\mathrm{M} 28 \cdot 0$ & 27.24 & 40 & 0.00 \\
$\mathrm{M} 20 \cdot 25$ & 19.46 & 40 & 0.25 & $\mathrm{M} 28 \cdot 25$ & 27.24 & 40 & 0.25 \\
$\mathrm{M} 20 \cdot 50$ & 19.46 & 40 & 0.50 & $\mathrm{M} 28 \cdot 50$ & 27.24 & 40 & 0.50 \\
$\mathrm{~L} 20 \cdot 0$ & 19.45 & 50 & 0.00 & & & & \\
$\mathrm{~L} 20 \cdot 25$ & 19.45 & 50 & 0.25 & $\mathrm{~S} 32 \cdot 0$ & 31.11 & 30 & 0.00 \\
$\mathrm{~L} 20 \cdot 50$ & 19.45 & 50 & 0.50 & $\mathrm{~S} 32 \cdot 25$ & 31.11 & 30 & 0.25 \\
& & & & $\mathrm{~S} 32 \cdot 50$ & 31.11 & 30 & 0.50 \\
$\mathrm{~S} 24 \cdot 0$ & 23.38 & 30 & 0.00 & $\mathrm{M} 32 \cdot 0$ & 31.24 & 40 & 0.00 \\
$\mathrm{~S} 24 \cdot 25$ & 23.38 & 30 & 0.25 & $\mathrm{M} 32 \cdot 25$ & 31.24 & 40 & 0.25 \\
$\mathrm{~S} 24 \cdot 50$ & 23.38 & 30 & 0.50 & $\mathrm{M} 32 \cdot 50$ & 31.22 & 40 & 0.50 \\
$\mathrm{M} 24 \cdot 0$ & 23.40 & 40 & 0.00 & & & & \\
$\mathrm{M} 24 \cdot 25$ & 23.40 & 40 & 0.25 & $\mathrm{~S} 34 \cdot 0$ & 33.05 & 30 & 0.00 \\
$\mathrm{M} 24 \cdot 50$ & 23.40 & 40 & 0.50 & $\mathrm{~S} 34 \cdot 25$ & 33.05 & 30 & 0.25 \\
$\mathrm{~L} 24 \cdot 0$ & 23.36 & 50 & 0.00 & $\mathrm{~S} 34 \cdot 50$ & 33.18 & 30 & 0.50 \\
$\mathrm{~L} 24 \cdot 25$ & 23.36 & 50 & 0.25 & & & & \\
$\mathrm{~L} 24 \cdot 50$ & 23.36 & 50 & 0.50 & & & & \\
\hline
\end{tabular}

かい部材, $\mathrm{M}$ は $\lambda=40$ の部材, $\mathrm{L}$ は $\lambda=50$ の長い部材 を表し, 次の数字 20,24 等は設計幅厚比, 最後の数字 は軸力比の\%表示である。

\section{3 実験結果と予測値の比較}

実験における最大耐力点に対応する部材角 4 から算 出した変形能力 $e \eta_{\psi}$ と式 $(24)^{\prime},(36)^{\prime},(39)^{\prime},(40)^{\prime}$ を 用いて予測した変形能力 ${ }_{c} \eta_{\psi}$ を比較したものを Table 2 に示す。

幅厚比の大きい試験体では，局部座屈が発生して最大 耐力に達したあ.と急激な耐力低下が起こるので，最大耐 力およびその時の変形を正確にとらえることは技術的に 難かしい, しかも幅厚比が大きくなると最大耐力に達す るまでの変形量が小さくなるので変形能力に換算する場 合に大きな誤差を生ずる。よって実験結果の整理におい ては, 最大耐力点に対応する部材角 $\psi$ を用いた変形能 力 $\eta_{\psi} \eta_{\psi}$ と, 最大耐力点をすぎて耐力が $95 \%$ まで低下し た点における部材角を用いた変形能力 $\left({ }_{e} \eta_{\psi}\right)_{R}$ の二つを算 出した。

この結果から次のことが観察ざれる。

幅厚比の小さい領域では実験値と理論値の対応は良好 であるが，幅厚比が大きくなるに従い，実験値は理論値 より低い值となってゆく。これは幅厚比の大きい場合に は最大耐力とその時の変形を正確にとらえることが難し いという前記の実験技術的側面と，ひずみ硬化域の初期 においてはひずみ硬化係数 $E_{s t}$ は本論文に用いた平均的
ひずみ硬化係数より大きいという理論の単純化に帰因す る側面に関係するものと思われる。しかしながら最大耐 力点を少し過ぎた点での変形能力（例えば Table 2 の $\left.\left({ }_{e} \eta_{\psi}\right)_{R}\right)$ が理論値と比較的良い対応を示すことを考える と，この予測値は実用的には十分価値のあるものと言え るであろう。幅厚比, 軸力比の大きさがある限度を超え ると（例えば S.M $28 \cdot 50$, S. M 32.50 等) $s_{c r}$ が 1 より 小さくなるので本理論式からは変形能力は評価できな い。降伏荷重の近傍では荷重一変形関係は直線ではなく なるので実際には若干の変形能力が期待できるのである が,この応力レベルでの材料の非線形特性にはばらつき が大きく理論的追求は無理である。

次に荷重-変形関係の比較を行う。表現の簡単なはり の場合 $(\rho=0)$ から先に行う。

2.1 において応力上昇率 $s$ をより一般的に圧縮フラン ジの応力度の降伏点に対する上昇率と考えると, 片持ば り固定端の曲げモーメントは $s M,((9)$ 式), であり, 降伏モーメント（全塑性モーメント $M_{\rho}$ ) で無次元化す ると

$$
\frac{M}{M_{p}}=s
$$

となる。

この時の変形は 2.2 の (36) 式で与えられ,

$$
\eta_{\psi}=\frac{\psi}{\psi_{y}}-1=\frac{s-1}{2 s^{2}}\left[\frac{E}{E_{s t}}(s-1)(1+2 s)\right.
$$


Table 2 Comparison of experimental and theoretical deformation capacities

\begin{tabular}{|l|c|cc||c|c|cc|}
\hline \multirow{2}{*}{ Code } & Theory & \multicolumn{2}{|c||}{ Experimental } & \multirow{2}{*}{ Code } & \multicolumn{2}{|c|}{ Theory } & \multicolumn{2}{|c|}{ Experimental } \\
\cline { 3 - 4 } & ${ }^{\prime} \eta_{\psi}$ & ${ }_{e} \eta_{\psi}$ & $\left({ }_{e} \eta_{\psi}\right)_{R}$ & & ${ }_{c} \eta_{\psi}$ & ${ }_{e} \eta_{\psi}$ & $\left({ }_{e} \eta_{\psi}\right)_{R}$ \\
\hline $\mathrm{S} 20 \cdot 0$ & 7.53 & 7.84 & 15.0 & $\mathrm{~S} 28 \cdot 0$ & 4.06 & 3.14 & 6.2 \\
$\mathrm{~S} 20 \cdot 25$ & 4.52 & 5.49 & 7.6 & $\mathrm{~S} 28 \cdot 25$ & 1.30 & 1.49 & 2.5 \\
$\mathrm{~S} 20 \cdot 50$ & 5.87 & 5.63 & 8.5 & $\mathrm{~S} 28 \cdot 50$ & - & 1.14 & 1.7 \\
$\mathrm{M} 20 \cdot 0$ & 7.46 & 6.58 & 7.2 & $\mathrm{M} 28 \cdot 0$ & 4.15 & 1.11 & 3.8 \\
$\mathrm{M} 20 \cdot 25$ & 4.49 & 4.75 & 11.7 & $\mathrm{M} 28 \cdot 25$ & $\cdot 1.02$ & 0.75 & 1.4 \\
$\mathrm{M} 20 \cdot 50$ & 5.83 & 5.63 & 8.4 & $\mathrm{M} 28 \cdot 50$ & - & 0.79 & 1.2 \\
$\mathrm{~L} 20 \cdot 0$ & 7.51 & 5.95 & 9.8 & & & & \\
$\mathrm{~L} 20 \cdot 25$ & 4.50 & 3.86 & 6.2 & $\mathrm{~S} 32 \cdot 0$ & 2.43 & 0.93 & 3.9 \\
$\mathrm{~L} 20 \cdot 50$ & 5.83 & 5.47 & - & $\mathrm{S} 32 \cdot 25$ & 0.21 & 0.94 & 1.7 \\
& & & & $\mathrm{~S} 32 \cdot 50$ & - & 0.77 & 1.2 \\
$\mathrm{~S} 24 \cdot 0$ & 5.82 & 5.04 & 8.6 & $\mathrm{M} 32 \cdot 0$ & 2.51 & 0.74 & 3.0 \\
$\mathrm{~S} 24 \cdot 25$ & 2.84 & 1.95 & 3.6 & $\mathrm{M} 32 \cdot 25$ & 0.17 & 0.57 & 1.2 \\
$\mathrm{~S} 24 \cdot 50$ & 2.40 & 2.07 & 3.0 & $\mathrm{M} 32 \cdot 50$ & - & 0.69 & 1.0 \\
$\mathrm{M} 24 \cdot 0$ & 5.49 & 3.67 & 7.2 & & & & \\
$\mathrm{M} 24 \cdot 25$ & 2.84 & 1.95 & 3.5 & $\mathrm{~S} 34 \cdot 0$ & 1.84 & 0.74 & 3.3 \\
$\mathrm{M} 24 \cdot 50$ & 2.40 & 2.05 & 3.1 & $\mathrm{~S} 34 \cdot 25$ & - & 0.47 & 1.2 \\
$\mathrm{~L} 24 \cdot 0$ & 5.82 & 2.89 & 5.5 & $\mathrm{~S} 34 \cdot 50$ & - & 0.64 & 1.0 \\
$\mathrm{~L} 24 \cdot 25$ & 2.84 & 1.32 & 2.7 & & & & \\
$\mathrm{~L} 24 \cdot 50$ & 2.44 & 1.21 & 2.0 & & & & \\
\hline
\end{tabular}

$$
\left.+3\left(\frac{\varepsilon_{\rho}}{\varepsilon_{y}}\right)(1+s)\right]
$$

即ち

$$
\frac{\psi}{\psi_{y}}=\frac{s-1}{2 s^{2}}\left[\frac{E}{E_{s t}}(s-1)(1+2 s)+3\left(\frac{\varepsilon_{p}}{\varepsilon_{y}}\right)(1+s)\right]+1
$$

である。

(42)，(43）式は，圧縮フランジ応力レベル $s$ を媒介 変数亡する荷重-変形関係を与える。そして, 圧縮フラ ンジ応力レベルが $(39)^{\prime}$ 式で与えられる $s_{c r}$ に達すると， フランジは崩壊するので上式は成立しなくなる。

片持ばりが定軸圧縮力と曲げをうける場合は，実験に おいては（41）式に示すように固定端モーメント（実験 ではスパン中央モーメント）を軸力による付加モーメン 卜を考慮して評価している。

(41) 式, $M=\rho P_{y} \delta_{0}+\frac{Q L}{2}$ において $\frac{Q L}{2}$ は 2.1 の (3) 式， $\delta_{0}$ は2.2の (18) 式に近似的に等しい $\left(\delta_{0}=Y l, s\right.$ を一般的な応力上昇率と考えているから，サブスクリプ トを除いている)。

故に

$$
\begin{aligned}
M= & (s-\rho) M_{\rho}+\rho P_{y} \cdot \frac{(s-1) l^{2}}{2(s-\rho)^{2}} \\
& \cdot\left[\frac{M_{\rho}}{3 D}(s-1)(1+2 s-3 \rho)+(s+1-2 \rho) \phi_{\rho}\right]
\end{aligned}
$$

$$
\begin{aligned}
\frac{M}{M_{y}}= & \frac{M}{M_{\rho c}}=\frac{s-\rho}{1-\rho}+\frac{P_{y}}{M_{\rho}} \cdot \frac{\rho}{1-\rho} \cdot \frac{(s-1) l^{2}}{2(s-\rho)^{2}} \\
& \cdot\left[\frac{M_{\rho}}{3 D}(s-1)(1+2 s-3 \rho)+(s+1-2 \rho) \phi_{p}\right] \\
= & \frac{s-\rho}{1-\rho}+\frac{\rho(s-1)}{(1-\rho)(s-\rho)^{2}}\left[\frac{\sigma_{y}}{3 E_{s t}}(s-1)\right. \\
& \left.\cdot(1+2 s-3 \rho)+(1+s-2 \rho) \varepsilon_{\rho}\right]\left(\frac{l}{h}\right)^{2} .
\end{aligned}
$$

ここで実験では部材長 $L$ を用いて， $\lambda=L / i$ で定義す る細長比で部材寸法を規定している。2 章の解析との対 応は, $L=2 l, i=h / 2$ であるから $l / h=\lambda / 4$ である。よっ $\tau$,

$$
\begin{aligned}
\frac{M}{M_{y}}= & \frac{s-\rho}{1-\rho}+\frac{\rho(s-1)}{(1-\rho)(s-\rho)^{2}}\left[\frac{\sigma_{y}}{3 E_{s t}}(s-1)\right. \\
& \left.\cdot(1+2 s-3 \rho)+(1+s-2 \rho) \varepsilon_{\rho}\right]\left(\frac{\lambda}{4}\right)^{2}
\end{aligned}
$$

この時の変形は 2.2 の $(24)$ 式で与えられ

$$
\begin{aligned}
\eta_{\psi}= & \frac{\psi}{\phi_{y}}-1=\frac{s-1}{4(s-\rho)^{2}(1-\rho)}\left[\frac{E}{E_{s t}}(s-1)\right. \\
& \left.\cdot(1+2 s-3 \rho)+3\left(\frac{\varepsilon_{\rho}}{\varepsilon_{y}}\right)(1+s-2 \rho)\right]
\end{aligned}
$$

すなわち

$$
\begin{aligned}
\frac{\psi}{\psi_{y}}= & \frac{s-1}{4(s-\rho)^{2}(1-\rho)}\left[\frac{E}{E_{s t}}(s-1)(1+2 s-3 \rho)\right. \\
& \left.+3\left(\frac{\varepsilon_{p}}{\varepsilon_{y}}\right)(1+s-2 \rho)\right]+1 \cdots \cdots \cdots \cdots \cdots \cdots(45)
\end{aligned}
$$



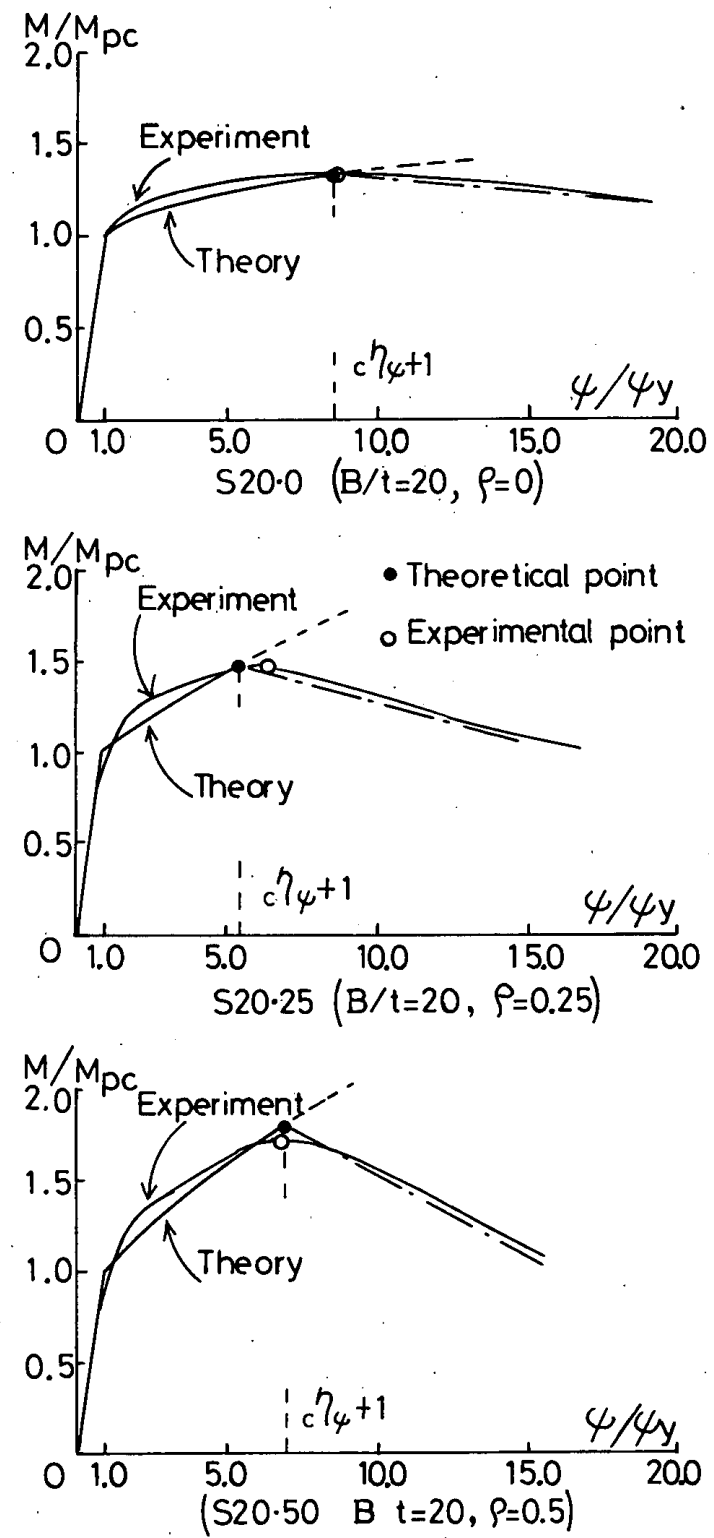

Fig. 11 Comparison of load-deflexion relationships

である。

(44)，(45）式は $s$ を媒介変数とする beam-column の 荷重-変形関係を与える。はりの場合と同様に $s$ が $(39)^{\prime}$ 式で与えられる $s_{c r}$ に達するとフランジは崩壊す るので，この式は成立しなくなる。

Fig. 11 は既に得た材料特性值 $\sigma_{y}=4.41 \mathrm{t} / \mathrm{cm}^{2}, E_{s t}=$ $42.03 \mathrm{t} / \mathrm{cm}^{2}, \varepsilon_{\rho}=0.00844$ を用いて, 試験体 S 20.0, $\mathrm{S} 20 \cdot 25, \mathrm{~S} 20 \cdot 50$ について上式による予測曲線を画き 実験曲線との比較を行ったものである。座屈崩壊後の 1 , 点鎖線は定性的説明のために任意に引いたものである。

\section{5. 結 び}

比較的降伏比の低い 60 キロ級高張力鋼よりなる正方 形中空断面を有する定軸力下で曲げをうける部材および はりを対象とし，その最大耐力が断面の局部座屈崩壊に よって支配される場合について，部材の崩壊に至るまで の変形能力を解析し，それぞれ $(24)^{\prime}$ および $(36)^{\prime}$ 式 を得た (それぞれの式は $(39)^{\prime}$ 式と組合わせて用いる)。 これらの予測式と実験值との対応は実用的に満足すべき ものであった。

これらの式は変形能力の要求値に応じて, これを満足 する幅厚比の制限値を与えるものである。

\section{引用文献}

1）加藤 勉：閉断面部材の局部座屈と変形能力, 日本建築 学会構造系椧文報告集, 第 378 号, pp. $27 \sim 36,1987$ 年 8 月

2) Ben Kato, Deformation Capacity of Steel Structures, Journal of Constructional Steel Research, Vol. 17, 1990 Nos. 1-2. Elsevier Applied Science, London \& New York

3）井上哲郎，桑村 仁：降伏棚のある低降伏比 60 キ口高張 力鎆短柱の応力ーひずみ特性 (十字形および箱形断面), 日本学術会議, 建築学会, 構造工学論文集, Vol. 37 B, 1991 年 3 月

4）井上哲郎：低降伏比高張力鎆箱形断面梁およびビームコ ラムの終局耐力と変形能力, 日本学術会議, 建築学会, 構造工学論文集, Vol. 38 B, 1992 年 3 月

（1992 年 6 月 30 日原稿受理, 1992 年 11 月 2 日採用決定） 